\title{
Peran Pemerintah Desa Jerora Satu terhadap Kebijakan Perlindungan Lingkungan Desa
}

\author{
Nikodimus \\ Fakultas Ilmu Sosial dan Ilmu Politik Universitas Kapuas Sintang \\ Jl. Y.C.Oevang Oeray Nomor 92 Desa Baning Kota \\ Email: nangabayan@gmail.com
}

\begin{abstract}
Abstrak: Penelitian ini bertujuan untuk melakukan analisis, deskripsi dan menjelaskan secara mendalam tentang Peran Pemerintah terhadap Perlindungan lingkungan Desa. berbagai aspek yang terkait dengan permasalahan kebijakan perlindungan lingkungan Desa dan upaya-upaya yang dilakukan dam menjaga dan merawat lingkungan Desa. Penelitian ini mengacu pada sifat-sifat penelitian kualitatis dan deskriptif. Beberapa subjek penelitian yang telah ditentukan sebagai informan atau narasumber Kepala Desa Jerora satu Badan Permusyawaratan Desa, dan Masyarakat. Hasil penelitian menunjukkan bahwa peran pemerintah Desa terhadap kebijakan perlindungan lingkungan Desa terus di tingkatkan oleh pemerintah Desa, namum beitu masih ada juga kendala pihak pemerintah desa dalam menjaga dan merawat lingkungan di tingkat Desa. Berbagai upaya yang dilakukan oleh para unsur Desa dalam menerapkan kebijakan perlindungan lingkungan Desa, diantaranya dengan melakukan koordinasi atau sosialisasi kepada masyarakat agar tetap berperan serta dalam menjaga dan merawai lingkungan di wilayahnya masingmasing. Di samping itu di sarankan kepada pemerintah Desa untuk selalu memberikan informasi yang bermanfaat kepada masyrakat bahwa manfaat menjaga dan merawat lingkungan itu sangat penting bagi kehidupan yang akan datang.
\end{abstract}

Kata Kunci: Kebijakan, Lingkungan, Desa.

Pemerintah merupakan pejabat bertugas memberikan perhatian lebih kepada kelompok masyarakat secara umum, diantaranya dalam menerapkan kebijak perlindungan lingkungan di tingakt Desa. Dalam menjalankan suatu kebijakan pemeritnah Desa harus benar benar menerapkan suatu peraturan pemerintah yang menjaga lingkungan untuk di lestarikan agar Desa juga memiliki lingkungan yang bisa di gunakan untuk pembangunan di tingkat Desa. Di samping itu Pemerintah telah membangun dalam menciptakan dalam sistem desentralisasi. Hal itupemerintah menganut pada sumber hukum-hukum yang menganut pada undang-undang No 6 Tahun 2014 hal ini pemerintah pusat tentang pemerintah Desa.

Pada tataran menerapkan kebijakan pelindungan lingkungan Desa yang bersih rapi dan ramah lingkungan. Ini bisa terjadi bila semua komponen semua terlibat untuk melakukan dan mematuhi semua kebijakan yang ada di tingkat Desa. Selain itu juga ketika kondisi Desa sudah tertata dengan rapi dan semua lingkungan bisa terjaga dengan baik maka desa tersebut sangat mungkin menjadi objek wisata dan menghasilkan pendapatan dan mengarahkan sektor ini sebagai investasi yang menguntungkan kedepannya serta memberikan asumsi yang baik bagi para masyarakat dalam meningkatkan roda perekonomian mereka.

Wisata yang berpotensial menghasilkan pendapatan dan mengarahkan sector ini sebagai investasi yang menguntungkan kedepannya serta memberikan asumsi yang baik bagi para wisatawan dalam kemudahan prosedur untuk mengikat daya tarik. Namun tidak hanya pendapatan bagi pemasukan pemerintah tapi juga kesejahteraan untuk masyarakat di sekitar objek wisata. Penanganan objek wisata pada peningkatan sumber daya manusia yang memadai secara konsisten, menyeluruh, terpadu dan sistematis oleh Pemerintah kepada masyarakat perlu dilakukan karena keberhasilan upaya-upaya strategi pengembangan dan pengelolaan kegiatan pariwisata merupakan suatu tindakan, baik itu tindakan pemerintah, swasta maupun masyarakat sehingga terciptanya kerjasama yang baik dan harmonis dan mewujudkan sapta pesona.

Keberadaan sektor pariwisata dalam suatu wilayah dapat memberikan dampak positif maupun negatif. Namun, pada dasarnya tergantung pada manajemen dan tata pengelolaan kepariwisataan yang diperankan oleh segenap pemangku kepentingan (stakeholders) baik dari unsur pemerintah-industri masyarakat yang ada pada wilayah tersebut. Pencapaian tujuan dan misi pembangunan kepa-riwisataan yang baik, berkelanjutan (sustainable tourism) dan berwawasan lingkungan hanya akan dapat terlaksana manakala dalam proses pencapaiannya dapat dilakukan melalui tata kelola kepa-riwisataan yang baik (good tourism governance). Undang-Undang mengenai 
Otonomi Daerah telah disyahkan pemerintah dengan persetujuan DPR RI, pada tanggal 4 Mei 1999, dan mulai diberlakukan secara efektif pada tahun 2001. Untuk mere-alisasikan UndangUndang Otonomi Daerah tersebut, Departemen Dalam Negeri telah mengeluarkan buku pedoman tentang Visi, Misi, Strategi dan Kebijakan Pemberdayaan Masyarakat Desa, se-bagai pegangan bagi aparat pemerintah di daerah. Menurut pedoman tersebut, pada pokoknya pem-berdayaan masyarakat mempunyai dua makna pokok, yaitu: 1)Meningkatkan kemampuan masyarakat melalui pelaksanaan berbagai kebijakan program pembangunan, 2) Meningkatkan kemandirian masyarakat melalui pemberian wewenang secara proporsional kepada masyarakat dalam mengambil keputusan.

Undang-Undang Nomor 32 Tahun 2009 tentang Perlindungan dan Pengelolaan Lingkungan Hidup yang dimaksud dengan perlindungan dan pengelolaan lingkungan hidup adalah upaya sistematis dan terpadu yang dilakukan untuk melestarikan fungsi lingkungan hidup dan mencegah terjadinya pencemaran dan/atau kerusakan lingkungan hidup yang meliputi perencanaan, pemanfaatan, pengendalian, pemeliharaan, pengawasan dan penegakan hukum.

Dari penjelasan tersebut, jelas masyarakat diberi kesem-patan penuh dalam perencanaan dan pelaksanaan pembangunan. Disitu ditegaskan bahwa tugas birokrasi di daerah hanyalah sebagai fasilitator (pelayanan). Kreativitas masyarakat dipacu dan didorong berkembang. Kemudian Departemen Pariwisata dalam kiprah memberdayakan masyarakat desa telah menyusun program pembangunan desa.

Dihubungkan dengan pedoman Visi, Misi, Strategi dan Kebijakan Pemberdayaan Masyarakat desa tersebut di atas, pembangunan desa wisata ini nampaknya sangat relevan dengan pedoman tersebut. Dengan demikian pembangunan desa wisata dapat dikatakan merupakan tindak lanjut dari pelaksa-naan Undang-Undang Otonomi Daerah. Untuk semakin mewujudkan semangat otonomi daerah hingga pada level pemerintahan desa dan untuk mengatasi berbagai permasalahan yang terjadi dalam wilayah desa dan mewujudkan ke-mandirian serta kesejahteraan bagi wilayah desa maka pemerintah pada Tahun 2014 mengeluarkan ke-bijakan perundang-undangan baru yaitu Undang-Undang Nomor 6 Tahun 2014 tentang Desa. Munculnya undang-undang desa tersebut semakin memberi keleluasaan kepada desa untuk melakukan perencanaan, pengawasan, pengendalian dan mengevaluasi kebijakan-kebijakan yang dikeluarkan oleh desa. Dari uraian diatas perlu disadari oleh pemerintah daerah terutama pemerintah desa Jerora yang berperan penting dalam mengembangkan desa sehingga dapat mengangkat ekonomi desa apabila penerapan kebijakan lingkungan obyeknya dikelola dengan baik oleh pemerintah Desa maupun pihak-pihak atau elemen masyarakat Desa Jerora.

Selain menerapkan peratuturan pihak pemerintah Desa juga harus melakukan koordinasi yang menyeluruh kepada semua masyarakaat yang ada di Desa. Koordinasi pemerintahan sebagai salah satu fenomena dalam pemerintahan di Daerah merupakan aspek yang penting dalam rangka mencapai tujuan pemerintahan. Koordinasi pemerintahan adalah koordinasi yang dilaksanakan dalam organisasi pemerintahan, masalah kerja sama antara aparatur pemerintahan, dan pertalian satu sama lainnya. Sebagai suatu konsep, koordinasi mencakup beberapa unsur yang perlu diketahui seperti metode koordinasi, jenis-jenis koordinasi, aspek-aspek koordinasi dan faktor-faktor yang berpengaruh terhadap koordinasi. Lubis dan Husaini (1987) bahwa teori organisasi adalah sekumpulan ilmu pengetahuan yang membicaraan mekanisme kerjasama dua orang atau lebih secara sistematis untuk mencapai tujuan yang telah ditentukan. Teori organisasi merupakan sebuah teori untuk mempelajari kerjasama pada setiap individu. Hakekat kelompok dalam individu untuk mencapai tujuan beserta cara-cara yang ditempuh dengan menggunakan teori yang dapat menerangkan tingkah laku, terutama motivasi, individu dalam proses kerjasama.

Dalam Undang-Undang Nomor 32 Tahun 2004, permasalahan lingkungan hidup merupakan salah satu urusan wajib bagi pemerintah provinsi. Berikut merupakan urusan wajib yang menjadi kewenangan pemerintahan daerah provisnsi, yaitu: perencanaan dan pengendalian pembangunan; perencanaan, pemanfaatan, dan pengawasan tata ruang; penyelenggaraan ketertiban umum dan ketentraman masyarakat; penyediaan sarana dan prasarana umum; penanganan bidang kesehatan; penyelenggaraan pendidikan dan alokasi sumber daya manusia potensial; penanggulangan masalah sosial lintas kabupaten/kota; pelayanan bidang ketenagakerjaan lintas kabupaten/kota; fasilitas pengembangan koperasi, usaha kecil, dan menengah termasuk lintas kabupaten/kota; pengendalian lingkungan hidup; pelayanan pertanahan termasuk lintas kabupaten/kota; pelayanan kependudukan, dan catatan sipil; pelayanan administrasi umum pemerintahan; pelayanan administrasi penanaman modal termasuk lintas kabupaten/kota; penyelenggaraan pelayanan dasar lainnya yang belum dapat dilaksanakan oleh kabupaten/kota; urusan wajib lainnya yang diamanatkan oleh peraturan perundang-undangan. 
Sedangkan urusan pemerintahan provinsi yang bersifat pilihan meliputi urusan pemerintahan yang secara nyata ada dan berpotensi untuk meningkatkan kesejahteraan masyarakat sesuai dengan kondisi, kekhasan, dan potensi unggulan daerah yang bersangkutan.

Kebijakan yang akan dilakukan pemerintahan Desa Jerora Satu dalam menjaga dan merawat lingkungan di Desa dangan menyediakan sarana dan prasara atau faktor fasilitas dan infrastruktur yaitu menyediakan tempat pembuangan sampah bagi masarakat, memberikan sosialisassi dan penyuluhan bagi masyarakat untuk menjaga dan merawat lingkungan di sekitar masingmasing. Perilaku masyarakat ini sudah memberikan dampak positif bagi pihak pemerintah Desa dalam menjaga dan merawat lingkungan Desa.Selain itu dalam menerapkan kebijakan pemerintah di bidang lingkungan ada beberapa Fasilitas dan infrastruktur yang menuju keobjek wisata Danau Jamelak.

\section{Metode Penelitian}

Desain Penelitian yang digunakan yaitu deskriptif analisis yang berupaya menggambarkan kondisi yang terjadi berdasarkan kenyataan apa adanya. Populasi penelitian yaitu seluruh masyarakat yang ada di Desa Jerora Satu, Sedangkan sampel penelitian yaitu beberapa orang dari populasi yang dianggap dapat mewakili yaitu: 1) Kepala Desa Jerora Satu sebagai informan kunci (Key Informant), dipilih karena yang bersangkutan menguasai informasi dan persoalan yang sedang diteliti, 2) BPD desa Jerora Satu sebagai informan lanjutan, 3) Kepala Dusun dan 4) Perwakilan Tokoh Masyarakat.

Instrumen penelitian yang digunakan yaitu: Pedoman wawancara, yaitu suatu daftar pertanyaan yang telah disusun sebelumnya, yang bersifat pertanyaan-pertanyaan pokok untuk mendapatkan data atau keterangan dari subyek penelitian. Sebelum melakukan penelitian peneliti membuat daftar pertanyaan yang kemudian menjadi pedoman untuk bertanya kepada sampel penelitian sehingga akan diperoleh gambaran dari jawaban yang sesuai dengan konteks pertanyaan yang diajukan. Setelah itu peneliti mengklasifikasikan berbagai jawaban yang relevan dengan penelitian agar tersusun secara sistemtis, setelah itu peneliti menginterpretasikan jawaban dari sampel penelitian tersebut menjadi kalimatkalimat yang sesuai dengan kaidah dalam karya ilmiah. Panduan Observasi, yaitu pedoman yang digunakan dalam rangka memperoleh data dan informasi yang belum terjaring

melalui wawancara, sekaligus mengecek kebenaran informasi dari responden dan informan. Dalam proses observasi tersebut peneliti membuat panduan pengamatan dengan berbagai kriteria berdasarkan pada tujuan penelitian agar dapat dengan mudah memperoleh data-data pengamatan setelah itu data-data hasil pengamatan di deskripsikan ke dalam kalimat-kalimat yang sesuai dengan konteks penelitian.Teknik pengumpulan data dengan cara wawancara dan observasi. Menurut Sugiono (2014:85) analisis deskriptif adalah usaha untuk menyederhanakan sekaligus menjelaskan bagian dari keseluruhan langkah-langkahklasifikasi dan kategori sehingga dapat tersusun suatu rangkaian deskripsi yang sistematis sehingga memperoleh suatu kesimpulan.Proses kategorisasi dan klasifikasi data dilakukan secara bertahap atas informasi para informan, serta hasil observasi ketika berada dilapangan dan kemudian dilakukan interpretasi data dalam kerangka teori dan pandangan konseptual yang telah ditentukan sesuai rencana.

Langkah terakhir yaitu penafsiran data, sebagaimana dikemukakan Moleong (2002:199200), diterapkan dua langkah yaitu : (a). Menentukan kategori dan kawasannya, yang bermakna mengelompokan data-data dari informan yang sesuai dengan aspek-aspek penelitian. (b). Interogasi terhadap data, yang bermakna mengajukan seperangkat pertanyaansehingga dapat mengungkapkan banyak persoalan dari data itu sendiri berdasarkan hasil interogasi data tersebut, dapat diketahui apakah data yang telah terkumpul tersebut sudah sesuai dengan masalah yang diteliti atau belum untuk mengungkapkan permasalahan sehingga dapat diinterpretasikan sampai dimana data dan informasi yang telah (atau belum) mendukung.Data primer dan data sekunder sebagai pendukung tersebut selanjutnya dianalisis berdasarkan pada katregori-kategori yang berhubungan dengan tujuan yang ingin diperoleh.

\section{HASIL DAN PEMBAHASAN Deskipsi Objek Penelitian}

Kabupaten Sintang merupakan salah satu daerah yang terletak di bagian timur propinsi Kalimantan Barat dengan ibukotanya Sintang. Kabupaten Sintang dengan Luas 21.638 km 2, menempati posisi strategis baik dalam kontek Nasional, Regional dan Internasional. Kabupaten Sintang yang secara administrative berbatasan langsung dengan Serawak (Malaysia Timur) serta berlanjut ke Brunai Darussalam berpotensi menjadi gerbang keluar masuk barang dan orang (outlet) dari Serawak maupun Brunai Darussalam melalui jalan darat. Kawasan perbatasan yang ada di Kabupaten Sintang meliputi kecamatan Ketunggau Hilir, Ketunggau Tengah dan Ketunggau Hulu dengan luas kawasannya 586.510 ha atau $18,17 \%$ luas wilayah Kabupaten Sintang dengan panjang perbatasan kurang lebih $143 \mathrm{~km}$. 
Ditinjau dari konteks Regional, Kabupaten Sintang terletak pada jalur pelayaran sungai besar yang dilalui dua sungai yaitu Sungai Kapuas dan Sungai Melawi. Selain itu daerah ini berada di jalur jalan lintas Pontianak-Putussibau yang merupakan urat nadi perekonomian Kalimantan Barat. Selain itu jalan darat yang menjadi jalan protokol penghubung beberapa Kabupaten yaitu kabupaten Kapuas Hulu dan juga Kabupaten Melawi melewati wilayah Kabupaten Sintang Sehingga potensi Kabupaten Sintang sebagai sentral perekonomian sangat strategis, oleh karena itu pembangunan sebagai tolak ukur bagi sutau daerah dalam meningkatkan kesejahteraan masyarakat harus mendapat perhatian yang serius baik dari pemerintah propinsi maupun dari pemerintah pusat.

Desa Jerora sendiri berada di Kecamatan Sintang yang terletak di jalur jalan poros Sintang Kapuas Hulu, Desa Jerora memiliki beberapa Dusun ialah Dusun Serabu. Mayoritas masyarakat yang menempati Desa Jerora adalah Suku Dayak, dan ada juga suku lain seperi Jawa, Bugis, Batak dan Melayu. Di samping itu masyarakat yang ada di Desa Jerora memiliki keyakinan yang berbeda, ada yang beragama Katolik, Protestan, Islam, Buda. Namun mayoritas masyarakat di Desa Jerora beragama katolik. Kehidupan sosial di Desaa jerora sangat haromis, dimana setiap suku agama saling menghargai antara sau dengan yang lainnya.

Selama ini pihak pemerintah Desa sudah melakukan himbauan kepada masyarakat tentang penggelolaan dalam menjaga lingkungan Desa. Lebih lanjut dijelaskan oleh kepala Desa Jerora Satu pihak pemerintah Desa juga selalu memberikan sosialisasi kepada masyarakat dalam menjaga dan merawat lingkungan sekitar. Penerapan kebijakan dalam menjaga lingkungan di Desa Jerora Satu merupakan bagian dari proses yang menjadi tanggung jawab dari pemerintah Desa, namun dalam hal menjaga dan merawat lingkungan semua menjadi bagian dan tanggung jawab warga masyarakat Desa.

Penerapan kebijakan dalam menjaga lingkungan di Desa tersebut sudah terlihat baik, namun ada beberapa kendala yang di dapati salah satunya ialah tingkat kesadaran masyarakat yang masih kurang dalam membantu pihak pemerintah untuk menjaga dan merawat lingkungan Desa. Di sisi lain juga dari hasil pengamatan yang dilakukan penulis adalah masih adanya masyarakat yang tidak mengetahui tentan kebijakan pemerintah dalam menjaga dan melestarikan lingkungan Desa, hal ini terlihat ketika masyarakat membuang sampah tidak pada tempatnya. Tingkat kesadaran masyarakat masih sangat minim dalam memahami kebijakan pemerintah untuk menjaga lingkungan.
Dalam menerapkan kebijakan terutama kebijakan dalam menjaga lingkungan sosialisasi dari pihak pemerintah Desa sudah pernah dilakukan dalam bentuk himbauan ke setiap Dusun, namun ketika dalam penerapan tetap masih ada masyarakat yang tidak memperhatikan himbauan tersebut.

Keberhasilan dalam proses pengembangan suatu Desa tidak dapat dilepaskan dari adanya campur tangan sebuah lembaga atau institusi lokal serta elemen masyarakat yang menjadi objek dalam penerapan peraturan tersebut, terutama dalam mengelola dan merawat lingkungan Desadalam hal ini stake holder harus bisa terlibat dalam menerapkan dan menjaga lingkungan.

\section{Kesimpulan}

Peran pemerintah Desa Jerora Satu terhadap kebijakan perlindungan lingkungan Desa diharapkan dapat menjadi acuan serta menjadi suatu kesepakatan antara masyarakat dan pihak pemerintah Desa. Selain itu kerjasama antar masyarakat dan pihak pemerinth Desa sangat menentukan dalam menjalankan kebijakan untuk mengelola lingkungan di Desa Jerora.

\section{Daftar Pustaka}

Moleong, Lexy J. 2013. Metode Penelitian Kualitatif. Edisi Revisi. Bandung : PT. Remaja Rosdakarya.

Sugiyono. 2014. Metode Penelitian Kuantitatif Kualitatif dan R\&D. Alfabeta, Bandung.

Lubis dan Husaini (1987) teori organisasi suatu pendekatan marko. Pusat antar universitas ilmu sosial universitas Indonesia, jakarta

Undang-Undang Nomor 32 Tahun 2009 tentang Perlindungan dan Pengelolaan Lingkungan Hidup

Undang-undang No 6 tahun 2014 tentang pemerintah Desa. 